\title{
Successful Prediction of In Vivo Hepatobiliary Clearances and Hepatic Concentrations of Rosuvastatin Using Sandwich-Cultured Rat Hepatocytes, Transporter-Expressing Cell Lines, and Quantitative Proteomics ${ }^{\text {住 }}$
}

\author{
Kazuya Ishida, Mohammed Ullah, Beáta Tóth, Viktoria Juhasz, and Jashvant D. Unadkat \\ Department of Pharmaceutics, University of Washington, Seattle, Washington (K.I., J.D.U.); Cellular Transport Group, \\ Pharmaceutical Sciences, Roche Innovation Centre Basel, F. Hoffmann-La Roche Ltd, Basel, Switzerland (M.U.); and SOLVO \\ Biotechnology, Budaörs, Hungary (B.T., V.J.)
}

Received April 27, 2017; accepted October 25, 2017

\begin{abstract}
We determined whether in vivo transporter-mediated hepatobiliary clearance (CL) and hepatic concentrations of rosuvastatin (RSV) in the rat could be predicted by transport activity in sandwich-cultured rat hepatocytes (SCRHs) and/or transporter-expressing cell lines scaled by differences in transporter protein expression between SCRHs, cell lines, and rat liver. The predicted hepatobiliary CLs and hepatic concentrations of RSV were compared with our previously published positron emission tomography imaging data. Sinusoidal uptake CL (CLs,uptake) and efflux (canalicular and sinusoidal) CLs of $\left[{ }^{3} \mathrm{H}\right]-R S V$ in SCRHs were evaluated in the presence and absence of $\mathrm{Ca}^{2+}$ and in the absence and presence of $1 \mathrm{mM}$ unlabeled RSV (to estimate passive diffusion $\mathrm{CL}$ ). $C L_{\text {uptake }}$ of RSV into cells expressing organic anion transporting polypeptide (Oatp) 1a1, 1a4, and $1 \mathrm{~b} 2$ was also determined. Protein expression of Oatps in SCRHs and
\end{abstract}

Oatp-expressing cells was quantified by liquid chromatography tandem mass spectrometry. SCRHs well predicted the in vivo RSV sinusoidal and canalicular efflux CLs but significantly underesti-

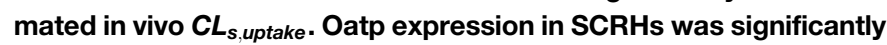
lower than that in the rat liver. $C L_{\text {s,uptake }}$, based on RSV $C L_{\text {uptake }}$ into Oatp-expressing cells (active transport) plus passive diffusion $\mathrm{CL}$ in SCRHs, scaled by the difference in protein expression in Oatp cells versus SCRH versus rat liver, was within 2-fold of that observed in SCRHs or in vivo. In vivo hepatic RSV concentrations were well predicted by Oatp-expressing cells after correcting $C L_{\text {s,uptake }}$ for Oatp protein expression. This is the first demonstration of the successful prediction of in vivo hepatobiliary CLs and hepatic concentrations of RSV using transporter-expressing cells and SCRHs.

\section{Introduction}

Hepatobiliary clearance (CL) of drugs is determined by transportermediated uptake, efflux, metabolism, or a combination of all three. Predicting in vivo hepatobiliary CL of drugs from in vitro data [in vitro-in vivo extrapolation (IVIVE)] is important for drug development including determining first in human dose and anticipating drug-drug interactions. Although the IVIVE of the metabolic CL of drugs has been

This work was supported by a Postdoctoral Fellowship to K.I. from F. Hoffmann-La Roche Ltd.

https://doi.org/10.1124/dmd.117.076539.

S This article has supplemental material available at dmd.aspetjournals.org. successful (Rostami-Hodjegan and Tucker, 2007; Soars et al., 2007; Rowland et al., 2011; Ke et al., 2014), the prediction of transporter-mediated CL remains a challenge (Abe et al., 2008; Zou et al., 2013).

Sandwich-cultured hepatocytes (SCHs) are considered to be the gold standard for estimating in vivo transporter-mediated hepatobiliary CLs of drugs (Swift et al., 2010; Pfeifer et al., 2014). However, such predictions typically underestimate the in vivo hepatic CL of the drug (Watanabe et al., 2009; Jones et al., 2012; Zou et al., 2013), requiring empirical scaling factors (Jones et al., 2012; Ménochet et al., 2012; Zou et al., 2013; Kimoto et al., 2017). This empirical scaling factor is drug dependent and therefore cannot be generalized. Others have proposed use of the relative activity factor (RAF) approach when using human hepatocytes to predict

ABBREVIATIONS: $\mathrm{CHO}$ cells, Chinese hamster ovary cells; $\mathrm{Cl}$, confidence interval; $\mathrm{CL}$, clearance; $C L_{b i l e}$, biliary $\mathrm{Clearance;} C L_{d e-l a c}$, delactonization clearance; $C L_{\text {lac }}$, lactonization clearance; $C L_{\text {met }}$, remainder metabolic clearance; $C L_{\text {passive, }}$, passive diffusion uptake clearance; $C L_{s, \text { efflux }}$, sinusoidal efflux clearance; $C L_{s \text {, uptake }}$, sinusoidal uptake clearance; $C L_{s, \text { uptake }}^{\text {Oatpo }}$, total sinusoidal uptake clearance estimated from organic anion

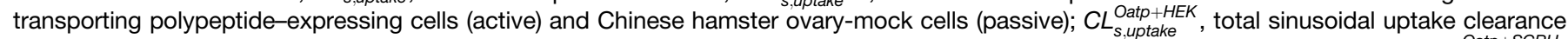
estimated from organic anion transporting polypeptide-expressing cells (active) and mock human embryo kidney $293 \mathrm{Cells}$ (passive); $C L_{s \text { uptake }}^{\text {Oatp } S C R H}$, total sinusoidal uptake clearance estimated from organic anion transporting polypeptide-expressing cells (active) and sandwich-cultured rat hepatocyte (passive); $C L_{s, \text { uptake }}^{P E T}$, total $C L_{s, \text { uptake }}$ in our positron emission tomography imaging study; $C L_{s, \text { uptake }}^{S C R H}$, total sinusoidal uptake clearance estimated from sandwich-cultured hepatocytes not corrected for organic anion transporting polypeptide protein expression; HBSS buffer, Hank's balanced salt solution buffer; HEK293, human embryo kidney 293; HPLC, high-performance liquid chromatography; IVIVE, in vitro-to-in vivo extrapolation; KH, Krebs-Henseleit; LC-MS/MS, liquid chromatography-tandem mass spectrometry; MRP/Mrp, multidrug resistance-associated protein; Ntcp, sodium taurocholate cotransporting polypeptide; OATP/Oatp, organic anion transporting polypeptide; PET, positron emission tomography; RAF, relative activity factor; RSV, rosuvastatin; SCH, sandwich-cultured hepatocyte; SCRH, sandwich-cultured rat hepatocyte; SD, Sprague Dawley; SDS, sodium dodecyl sulfate. 
transporter-mediated in vivo CL of drugs (Chapy et al., 2015). However, to date, the RAF approach has been used primarily to determine the fraction of drug transported by hepatocytes (Hirano et al., 2004, 2006; Yamashiro et al., 2006; Kitamura et al., 2008; Nakakariya et al., 2008a,b; Kunze et al., 2014). This is because the RAF can be used only when transporter-specific substrates are available for use both in vitro and in vivo. This requirement is a significant limitation for predicting organic anion transporting polypeptide (OATP)-dependent drug CL as most OATP substrates [e.g., rosuvastatin (RSV)] are transported by multiple OATPs. Therefore, alternative approaches are required to predict transportermediated CL of drugs. For this reason, we and others (Li et al., 2010; Bosgra et al., 2014; Prasad and Unadkat, 2015; Vildhede et al., 2016) have proposed that transporter-mediated hepatobiliary CL of drugs may be possible to estimate directly from transporter-expressing cell lines. The disadvantage of this approach is that the absolute abundance of the transporter protein in both the cell lines and liver tissue must be quantified. With the development of targeted quantitative proteomics, this disadvantage has been overcome (Ohtsuki et al., 2011; Bosgra et al., 2014; Prasad and Unadkat, 2014; Wang et al., 2015). Indeed, Bosgra et al. (2014) showed that the systemic CL of RSV in humans was well predicted using suspended primary human hepatocytes, OATP-expressing cell lines, and quantitative proteomics.

In addition to systemic CL, it is also important to predict drug concentrations in the target tissue (in the case of RSV, hepatic concentration) to predict drug efficacy/toxicity and the prediction of drug-drug interactions. As stated above, our ultimate goal is to predict transporter-mediated hepatobiliary CL of drugs and hepatic concentrations directly from transporter-expressing cell lines. Therefore, as a first step toward achieving this goal, using RSV as our model drug, we determined whether Oatp transporter-expressing cell lines and quantitative proteomics combined with sandwich-cultured rat hepatocytes (SCRHs) can predict the in vivo transporter-mediated hepatobiliary CL and hepatic concentrations of RSV observed in our positron emission tomography (PET) imaging study (He et al., 2014).

\section{Materials and Methods}

Materials. RSV (acid form) was purchased from Cayman Chemicals (Ann Arbor, MI). $\left[{ }^{3} \mathrm{H}\right]-\mathrm{RSV}$ sodium salt (acid form; $20 \mathrm{mCi} / \mathrm{mmol}$, radiochemical purity 99\%) was purchased from American Radiolabeled Chemicals (St. Louis, MO). RSV lactone was purchased from Toronto Research Chemicals (Toronto, ON, Canada). All other chemicals were of reagent or analytical grade and were purchased from other commercial suppliers.

SCRH. Freshly isolated SCRHs (adult male SD rats) plated into 24-well plates were purchased from Triangle Research Labs (Durham, NC) or Qualyst Transporter Solutions (Durham, NC). According to vendor instructions, after receiving SCRHs, the shipping medium was changed to maintenance medium (purchased from the vendors). Then, the maintenance medium (purchased from the vendors) was changed every 24 hours. The uptake and efflux experiments were conducted at about 96 hours after plating.

Uptake and Efflux of RSV in SCRH. The uptake and efflux of [ $\left.{ }^{3} \mathrm{H}\right]-\mathrm{RSV}$ was evaluated as previously described (B-CLEAR Technology; Qualyst Transporter Solutions) (Pfeifer et al., 2013b) with minor modifications. Briefly, after washing SCRHs $\left(0.35-0.4 \times 10^{6}\right.$ cells/well) twice with $500 \mu$ l of prewarmed $\mathrm{Ca}^{2+} / \mathrm{Mg}^{2}$ +-containing Hanks' balanced salt solution [HBSS (hereafter referred to as $\mathrm{Ca}^{2}$ ${ }^{+}$-containing HBSS)] or $500 \mu \mathrm{l}$ of $\mathrm{Ca}^{2+} / \mathrm{Mg}^{2+}$-free HBSS with $1 \mathrm{mM}$ EDTA (hereafter referred to as $\mathrm{Ca}^{2+}$-free HBSS), the SCRHs were first preincubated with $500 \mu \mathrm{l}$ of $\mathrm{Ca}^{2+}$-containing HBSS or $\mathrm{Ca}^{2+}$-free HBSS (to disrupt the canalicular tight junctions) for 10 minutes at $37^{\circ} \mathrm{C}$. The SCRHs were then incubated with $500 \mu \mathrm{l}$ of $0.5 \mu \mathrm{M}$ RSV containing $0.08-0.2 \mu \mathrm{Ci} /$ well $\left[{ }^{3} \mathrm{H}\right]-\mathrm{RSV}$ in $\mathrm{Ca}^{2+}$-containing HBSS at $37^{\circ} \mathrm{C}$. Then, at $2,5,10$, and 20 minutes of incubation with $0.5 \mu \mathrm{M} \mathrm{RSV}$, the $\mathrm{Ca}^{2}$ ${ }^{+}$-containing HBSS was collected and SCRHs were washed twice with ice-cold $\mathrm{Ca}^{2}$ ${ }^{+}$-containing or $\mathrm{Ca}^{2+}$-free HBSS. Then, $1 \mathrm{ml}$ of $2 \%$ SDS was added to each well to lyse the cells (uptake phase). To evaluate the efflux of RSV from the SCRHs, after 10 minutes of preincubation with $\mathrm{Ca}^{2+}$-containing or $\mathrm{Ca}^{2+}$-free HBSS, the SCRHs were incubated with $500 \mu 1$ of $0.5 \mu \mathrm{M}$ RSV containing $0.08-0.2 \mu \mathrm{Ci} /$ well $\left[{ }^{3} \mathrm{H}\right]-\mathrm{RSV}$ in $\mathrm{Ca}^{2+}$-containing HBSS at $37^{\circ} \mathrm{C}$ for 20 minutes. Then, $\mathrm{Ca}^{2+}$-containing HBSS was aspirated, and SCRHs were washed twice $(500 \mu \mathrm{l})$ with ice-cold $\mathrm{Ca}^{2+}$-containing or $\mathrm{Ca}^{2+}$-free HBSS. Then, SCRHs were incubated with $500 \mu \mathrm{l}$ of $\mathrm{RSV}$-free $\mathrm{Ca}^{2}$ ${ }^{+}$-containing or $\mathrm{Ca}^{2+}$-free HBSS for $2,5,10$, and 15 minutes at $37^{\circ} \mathrm{C}$. An aliquot of the $\mathrm{Ca}^{2+}$-containing and $\mathrm{Ca}^{2+}$-free HBSS was collected, and the SCRH were washed twice $(500 \mu \mathrm{l})$ with ice-cold $\mathrm{Ca}^{2+}$-containing or $\mathrm{Ca}^{2+}$-free HBSS. Then, $1 \mathrm{ml}$ of $2 \%$ SDS was added to each well to lyse the SCRHs (efflux phase). The total radioactivity in the samples was measured using a liquid scintillation counter (PerkinElmer, Waltham, MA). To inhibit all uptake transporters and to determine the passive diffusion uptake CL of the RSV into the hepatocytes, SCRHs were incubated with and without $1 \mathrm{mM}$ unlabeled RSV throughout the above time periods. The total protein concentration of cell lysate was measured with Pierce BCA Protein Assay Kit (Thermo Fisher Scientific, Rockford, IL), according to the manufacturer instructions. Uptake and efflux experiments in the absence and presence of $1 \mathrm{mM}$ unlabeled RSV were performed in six and five lots of SCRHs, respectively.

Determination of RSV and RSV Lactone in SCRH Samples by HighPerformance Liquid Chromatography Fractionation. Fifty to $100 \mu \mathrm{l}$ of SCRH samples (both cell lysates and buffer) were mixed with the same volume of acetonitrile (containing $20 \mu \mathrm{M}$ unlabeled RSV and $20 \mu \mathrm{M}$ of RSV lactone). After centrifuging the samples at $16,000 \mathrm{~g}$ and $4^{\circ} \mathrm{C}$ for 5 minutes, the supernatant (50-100 $\mu \mathrm{l}$ ) was analyzed by high-performance liquid chromatography (HPLC) (Alliance 2695; Waters, Milford, MA). RSV and RSV lactone were separated on a ZORBAX SB-C8 column (Agilent, Santa Clara, CA) $(3.5 \mu \mathrm{m}, 4.6 \times 100 \mathrm{~mm})$ using a mobile phase $(1 \mathrm{ml} / \mathrm{min})$ consisting of $20 \mathrm{mM} \mathrm{KH}_{2} \mathrm{PO}_{4}(\mathrm{pH} 2.5)$ and acetonitrile. The gradient was as follows: $40 \%$ acetonitrile (0-6 minutes); 40\%-55\% acetonitrile (6-10 minutes), 55\% acetonitrile (10-20 minutes); $55 \%-80 \%$ $\mathrm{KH}_{2} \mathrm{PO}_{4}$ (20-22 minutes); $80 \%$ acetonitrile (22-27 minutes); $80 \%-40 \%$ acetonitrile (27-29 minutes); and 40\% acetonitrile (29-30 minutes). UV absorbance of the analytes was monitored at $243 \mathrm{~nm}$, and fractions were collected every minute for liquid scintillation counting. RSV and its lactone eluted at $\sim 12$ and $\sim 17$ minutes, respectively. To determine the percentages of RSV and RSV lactone in the samples, the radioactivity associated with the unlabeled RSV and RSV lactone was expressed as a percentage of total radioactivity collected in the fractions.

Estimation of the Hepatobiliary CLs of RSV in SCRH. To estimate the hepatobiliary CLs of $\left[{ }^{3} \mathrm{H}\right]-\mathrm{RSV}$ in SCRHs in both the uptake and efflux phase, the following model (eqs. 1-6) was fitted to the data using the nonlinear regression package Phoenix (Certara, Princeton, NJ). The Poisson error model was used as the residual error model, as follows:

$$
\begin{aligned}
& \frac{d X_{\text {buffer }}^{+}}{d t}=C L_{s, \text { efflux }} \times \frac{X_{\text {cell }}^{+}}{V_{\text {cell }}}-C L_{s, \text { uptake }} \times \frac{X_{\text {buffer }}^{+}}{V_{\text {buffer }}}+K_{-} \text {flux } \times X_{\text {bile }} \\
& \frac{d X_{\text {buffer }}^{-}}{d t}=C L_{s, \text { efflux }} \times \frac{X_{\text {cell }}^{-}}{V_{\text {cell }}}+C L_{\text {bile }} \times \frac{X_{\text {cell }}^{-}}{V_{\text {cell }}}-C L_{s, \text { uptake }} \times \frac{X_{\text {buffer }}^{-}}{V_{\text {buffer }}} \\
& \frac{d X_{\text {cell }}^{+}}{d t}=C L_{s, \text { uptake }} \times \frac{X_{\text {buffer }}^{+}}{V_{\text {buffer }}}-C L_{s, \text { efflux }} \times \frac{X_{\text {cell }}^{+}}{V_{\text {cell }}}-C L_{\text {bile }} \times \frac{X_{\text {cell }}^{+}}{V_{\text {cell }}}-C L_{\text {lac }} \times \frac{X_{\text {cell }}^{+}}{V_{\text {cell }}} \\
& +C L_{d e-l a c} \times \frac{X_{\text {lac,cell }}^{+}}{V_{\text {cell }}}-C L_{\text {met }} \times \frac{X_{\text {cell }}^{+}}{V_{\text {cell }}} \\
& \frac{d X_{\text {cell }}^{-}}{d t}=C L_{s, \text { uptake }} \times \frac{X_{\text {buffer }}^{-}}{V_{\text {buffer }}}-C L_{s, \text { efflux }} \times \frac{X_{\text {cell }}^{-}}{V_{\text {cell }}}-C L_{\text {bile }} \times \frac{X_{\text {cell }}^{-}}{V_{\text {cell }}}-C L_{\text {lac }} \times \frac{X_{\text {cell }}^{-}}{V_{\text {cell }}} \\
& +C L_{\text {de }- \text { lac }} \times \frac{X_{\text {lac, cell }}^{-}}{V_{\text {cell }}}-C L_{\text {met }} \times \frac{X_{\text {cell }}^{-}}{V_{\text {cell }}} \\
& \frac{d X_{\text {bile }}}{d t}=C L_{\text {bile }} \times \frac{X_{\text {cell }}^{+}}{V_{\text {cell }}}-K_{-} \text {flux } \times X_{\text {bile }} \\
& \frac{d X_{\text {bile }+ \text { cell }}}{d t}=\frac{d X_{\text {bile }}}{d t}+\frac{d X_{\text {cell }}^{+}}{d t}
\end{aligned}
$$

where $X_{\text {buffer }}^{+}$and $X_{\text {buffer }}^{-}$indicate the amount of $\left[{ }^{3} \mathrm{H}\right]-\mathrm{RSV}$ in the $\mathrm{Ca}^{2+}$-containing and $\mathrm{Ca}^{2+}$-free HBSS, respectively. $X_{\text {cell }}^{+}$and $X_{\text {cell }}^{-}$indicate the amount of $\left[{ }^{3} \mathrm{H}\right]-\mathrm{RSV}$ in the cells incubated with $\mathrm{Ca}^{2+}$-containing and $\mathrm{Ca}^{2+}$-free HBSS, respectively. $X_{\text {bile }}$ is the amount of $\left[{ }^{3} \mathrm{H}\right]-\mathrm{RSV}$ in the bile pockets of SCRHs incubated with $\mathrm{Ca}^{2+}$-containing HBSS. $X_{\text {lac, cell }}^{+}$and $X_{\text {lac, cell }}^{-}$indicate the amount of $\left[{ }^{3} \mathrm{H}\right]-\mathrm{RSV}$ 
lactone in the cells incubated with $\mathrm{Ca}^{2+}$-containing and $\mathrm{Ca}^{2+}$-free HBSS, respectively. $C L_{\text {s.uptake }}, C l_{s, \text { effux }}$, and $C L_{\text {bile }}$ are the sinusoidal uptake, the sinusoidal efflux, and the biliary CLs of $\left[{ }^{3} \mathrm{H}\right]-\mathrm{RSV}$ respectively. $C L_{\text {lac }}$, $C L_{d e-l a c}$, and $C L_{m e t}$ are the metabolic CLs of $\left[{ }^{3} \mathrm{H}\right]-\mathrm{RSV}$ to the lactone, the metabolic CLs of $\left[{ }^{3} \mathrm{H}\right]-\mathrm{RSV}$ lactone to $\left[{ }^{3} \mathrm{H}\right]-\mathrm{RSV}$, and the remainder of metabolic CLs of $\left[{ }^{3} \mathrm{H}\right]-\mathrm{RSV}$, respectively. RSV is converted to the lactone form (RSV lactone), and RSV lactone is back-converted to the acid form (Nezasa et al., 2002). In addition, RSV is metabolized to the pentenoic acid derivative (minor metabolite; remainder metabolic CL) in the rat liver (Nezasa et al., 2002; Pfeifer et al., 2013a). $V_{\text {cell }}$ and $V_{\text {buffer }}$ represent the volume of SCRHs $(7.4 \mu 1 / \mathrm{mg}$ protein) (Pfeifer et al., 2013b) and buffer $(500 \mu l)$, respectively. $K_{-}$flux represents the rate constant of efflux of bile from the bile pocket due to "pulsing" of the bile canaliculi (Pfeifer et al., 2013b). If the 95\% confidence interval (CI) of a parameter encompassed zero, that parameter was fixed to zero. In addition, $C L_{l a c}, C L_{d e-l a c}$, $C L_{m e t}$, and $K_{-}$flux were assumed to be invariant for the two concentration of unlabeled RSV $(0.5 \mu \mathrm{M}$ and $1 \mathrm{mM})$.

RSV Uptake into CHO-Oatp1a1, HEK293-Oatp1a4, and HEK293Oatp1b2 Expressing Cells. CHO-Oatp1a1, HEK293-Oatp1a4, HEK293Oatp1b2, and their corresponding mock-transfected cells were a gift from SOLVO Biotechnology (Budaörs, Hungary). CHO-Oatp1a1 and CHO-mock cells, grown in $75-\mathrm{cm}^{2}$ flasks, were harvested using trypsin and were plated at a density of $0.25 \times 10^{6}$ cells $/ \mathrm{cm}^{2}$ in 24 -well plates. These cells were incubated with $5 \mathrm{mM}$ sodium butyrate about 24 hours before the transport experiments. HEK293Oatp1a4, HEK293-Oatp1b2, and HEK293-mock cells, grown in a $75-\mathrm{cm}^{2}$ flask with $3 \mu \mathrm{g} / \mathrm{ml}$ puromycin, were harvested using trypsin and plated at a density of $0.25 \times 10^{6}$ cells $/ \mathrm{cm}^{2}$ in a 24 -well poly-D-lysine-coated plates. These cells were also incubated with $3 \mu \mathrm{g} / \mathrm{ml}$ puromycin 24 hours before the transport experiments. The cells were washed three times with prewarmed Krebs-Henseleit (KH) buffer, then preincubated with the $\mathrm{KH}$ buffer at $37^{\circ} \mathrm{C}$ for 10 minutes. After preincubation, the cells were incubated with $500 \mu \mathrm{l}$ of $0.07 \mu \mathrm{M}$ RSV containing $0.2 \mu \mathrm{Ci} /$ well $\left[{ }^{3} \mathrm{H}\right]-\mathrm{RSV}$ at $37^{\circ} \mathrm{C}$ for 5 seconds (Oatp1a1) or 15 seconds (Oatp1a4 and Oatp1b2), a time period over which the uptake of $\left[{ }^{3} \mathrm{H}\right]-\mathrm{RSV}$ was assumed to be linear (Oatp1a1) or found to linear (Oatp1a4 and Oatp1b2; data not shown). The KH buffer containing RSV was aspirated, and the cells were washed three times with ice-cold $\mathrm{KH}$ buffer, and then $1 \mathrm{ml}$ of $2 \%$ SDS was added to lyse the cells. The total radioactivity and total protein concentration in the samples were measured as described above. The transporter-mediated uptake was calculated by subtracting the uptake of the drug in the mock cells from that in the transfected cells. The Oatp-mediated uptake CL of RSV into each Oatp cell line was calculated as the ratio of the rate of transporter-mediated uptake (unlabeled plus labeled RSV; in picomoles per minute per milligram total protein) and the total concentration of RSV in the medium $(0.07 \mu \mathrm{M})$. The passive diffusion-mediated uptake CL of RSV was calculated as above but using the uptake CL in mock-transfected cell lines. We also evaluated RSV uptake into CHO-Ntcp cells. However, RSV was not transported by Ntcp (data not shown).

Quantification of Transporters in SCRHs and Transporter-Expressing Cell Lines Using Surrogate Peptides and Quantitative Proteomics. The total cell membranes of SCRHs (only sufficient cells were available for three of six lots) and Oatp-expressing cell lines were isolated using Calbiochem ProteoExtract Native Membrane Protein Extraction Kit (EMD Millipore, Billerica, MA) according to the manufacturer instructions. Cell membranes were then reduced, denatured, alkylated, and digested as previously described with minor modifications (Wang et al., 2015). That is, $80 \mu \mathrm{l}$ of total membranes $(0.3-0.6 \mathrm{mg} / \mathrm{ml})$ were incubated with $10 \mu \mathrm{l}$ of $250 \mathrm{mM}$ dithiothreitol, $20 \mu \mathrm{l}$ of $10 \%$ sodium deoxycholate, $10 \mu \mathrm{l}$ of $10 \mathrm{mg} / \mathrm{ml}$ human serum albumin, and $40 \mu \mathrm{l}$ of $100 \mathrm{mM}$ ammonium bicarbonate $(\mathrm{pH} 7.8)$ at $95^{\circ} \mathrm{C}$ for 10 minutes. Then, the mixture was incubated with $20 \mu \mathrm{l}$ of $500 \mathrm{mM}$ iodoacetamide for 30 minutes at room temperature in the dark. To this mixture were added $0.5 \mathrm{ml}$ of methanol, $0.1 \mathrm{ml}$ of chloroform, and $0.4 \mathrm{ml}$ of Milli-Q Water (EMD Millipore). After centrifuging the samples at $16,000 \mathrm{~g}$ and $4^{\circ} \mathrm{C}$ for 5 minutes, the pellet was washed once with $1.0 \mathrm{ml}$ of methanol and resuspended in $60 \mu \mathrm{l}$ of $50 \mathrm{mM}$ ammonium bicarbonate. The extracted proteins were digested with $20 \mu 1$ of $0.16 \mu \mathrm{g} / \mu \mathrm{l}$ trypsin at $37^{\circ} \mathrm{C}$ for 18 hours. The digestion was stopped by adding $20 \mu \mathrm{l}$ of a chilled labeled peptide internal standard cocktail (in $80 \%$ acetonitrile solution with $0.2 \%$ formic acid) (Supplemental Table 2), and the samples were centrifuged at $5000 \mathrm{~g}$ and $4{ }^{\circ} \mathrm{C}$ for 5 minutes. Finally, $5 \mu \mathrm{l}$ of the supernatant was injected onto a LC-tandem mass spectrometry (LC-MS/MS) system to quantify the expression of the Oatp transporters in total cell membranes (expressed as femtomoles per microgram membrane protein).
Scaling $\boldsymbol{C L}_{\text {uptake }}$ from In Vitro to In Vivo. The intrinsic uptake CL $\left(C L_{\text {uptake }}\right)$ of RSV in the transporter-expressing cell lines were scaled to that in SCRHs (in vitro-to-in vitro extrapolation) (eq. 7) or in vivo (IVIVE, i.e., in liver tissue) (eq. 8) as follows:

$$
\begin{aligned}
C L_{s, \text { uptake }}\left(\text { scaled }_{\text {in vitro }- \text { to }- \text { in vitro }}\right)= & \sum\left(C L_{\text {uptake, Oatp }, i} \times \frac{\left[\text { Transporter }_{S C R H}\right]}{\left[\text { Transporter }_{\text {cells }}\right]}\right) \\
& +C L_{\text {passive }} \\
C L_{\text {s,uptake }}\left(\text { scaled }_{\text {in vitro }- \text { to }- \text { in vivo }}\right)= & \sum\left(C L_{\text {uptake, } \text { Oatp }, i} \times \frac{\left[\text { Transporter }_{\text {tissue }}\right]}{\left[\text { Transporter }_{\text {cells }}\right]}\right) \\
& +C L_{\text {passive }}
\end{aligned}
$$

where $C L_{\text {uptake,Oatp }, i}$ indicates $C L_{\text {uptake }}$ into the Oatp transporter-expressing cell line (i.e., Oatp 1a1, 1a4, or 1b2). $C L_{\text {passive }}$ indicates the passive diffusion uptake $\mathrm{CL}$ estimated from mock-transfected cell lines or SCRHs (in the presence of $1 \mathrm{mM}$ unlabeled RSV). As to which $C L_{\text {passive }}$ provides the best estimate of the observed in vitro (SCRHs) or in vivo $C L_{\text {s,uptake }}$ was also examined (see Results).

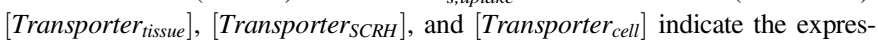
sion of each Oatp in SD rat liver, SCRHs, and transporter-expressing cells, respectively. Scaling Oatp $C L_{\text {uptake }}$ in cell lines to SCRHs and then in vivo using transporter expression data are equivalent to directly scaling the cell line $C L_{\text {uptake }}$ to that in vivo because the expression in SCRHs cancels out as follows:

$$
\begin{aligned}
C L_{s, \text { uptake }}\left(\text { scaled }_{\text {in vitro-to-in vivo }}\right)= & \sum\left(C L_{\text {uptake, Oatp }, i}\right. \\
& \left.\times \frac{\text { Transporter expression }_{\text {tissue }}}{\text { Transporter } \text { expression }_{\text {cells }}}\right)+C L_{\text {passive }}
\end{aligned}
$$

Then, all passive and active CLs (in milliliters per minute per milligram protein) estimated from SCRH or mock-transfected cell lines (CHO and HEK293 cells), were expressed in milliliters per minute per kilogram body weight, assuming $200 \mathrm{mg}$ of total protein of SCRHs or mock-transfected cells $/ \mathrm{g}$ liver and $40 \mathrm{~g}$ of liver $/ \mathrm{kg}$ b.wt. (Abe et al., 2008; Wolf et al., 2010). In addition, to compare the predicted and in vivo observed $C L_{s, \text { uptake }}$, the predicted $C L_{s, \text { uptake }}$ (in milliliters per minute per kilogram body weight) was scaled to that in vivo using fraction unbound in plasma (0.039) and blood/plasma ratio (0.67) of RSV in the rat (Fukuda et al., 2008). The total $C L_{s, \text { uptake }}$ values of RSV, calculated as the Oatp-mediated $C L_{\text {uptake }}$ [summation of $C L_{\text {uptake }}$ in each Oatp-expressing cells $\left.\left(C L_{s, \text { aptake }}^{\text {Oatp }}\right)\right]$ plus $C L_{\text {passive }}$ (estimated from SCRHs in the presence of $1 \mathrm{mM}$ unlabeled RSV, CHO-mock, or HEK293-mock cells) are indicated as $C L_{s \text {,uptake }}^{\text {Oatp }+S C R H}, C L_{s, \text { uptake }}^{\text {Oat }+C H O}$, and $C L_{\text {s.uptake }}^{\text {Oatp }+H E K}$, respectively. Statistically significant differences between the various groups were determined by the Welch's $t$ test (corrected for multiple comparisons).

Simulation of Hepatic Concentrations of RSV Using Hepatobiliary CLs of RSV Estimated from Oatp-Expressing Cells and SCRH. The hepatic concentrations of RSV were simulated using mean $\left[{ }^{3} \mathrm{H}\right]-\mathrm{RSV} C L_{s, \text { efflux }}$ and $C L_{\text {bile }}$ values estimated from SCRHs and $C L_{s, \text { uptake }}^{\text {Oatp }}$ and compared with our previous in vivo PET imaging data (He et al., 2014). The hepatic concentrations of RSV were simulated using the following equation and SAAMII (The Epsilon Group, Charlottesville, VA):

$$
\frac{d X_{\text {liver }}}{d t}=C L_{s, \text { uptake }}^{\text {Oatp }+S C R H} \cdot \frac{X_{\text {blood }}}{V_{\text {blood }}}-C L_{s, \text { efflux }} \cdot \frac{X_{\text {liver }}}{V_{\text {liver }}}-C L_{\text {bile }} \cdot \frac{X_{\text {liver }}}{V_{\text {liver }}}
$$

where $X_{\text {liver }}, X_{\text {blood }}, V_{\text {liver }}$, and $V_{\text {blood }}$ indicate the amount of RSV in the liver, the amount of RSV in blood, the volume of the liver, and the volume of blood, respectively. The lag time from blood to liver and liver to bile as well as $V_{\text {liver }}$ and $V_{\text {blood }}$ were fixed as reported previously (He et al., 2014).

\section{Results}

Cellular Accumulation and Efflux of $\left[{ }^{3} \mathrm{H}\right]-\mathrm{RSV}$ and Estimation of Hepatobiliary CL of RSV in SCRH. The morphology of SCRHs was good (Supplemental Fig. 1), and the biliary excretion index values 


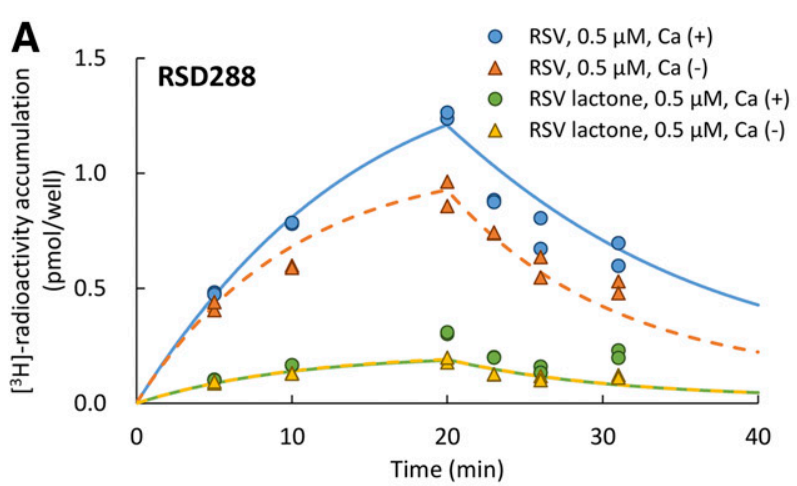

B

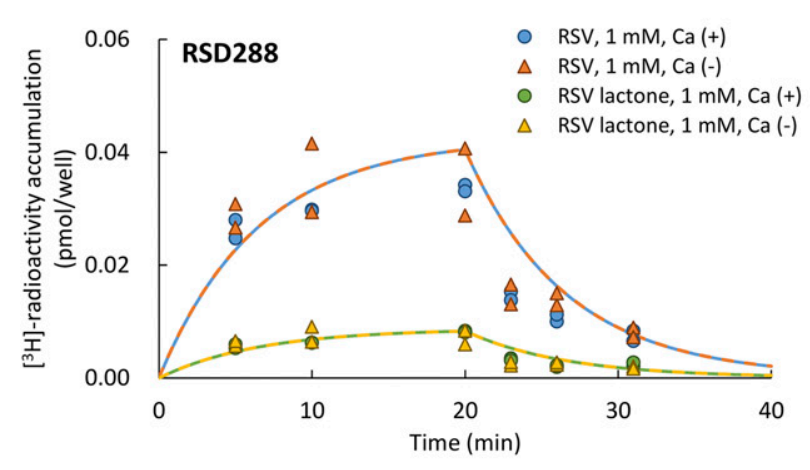

E

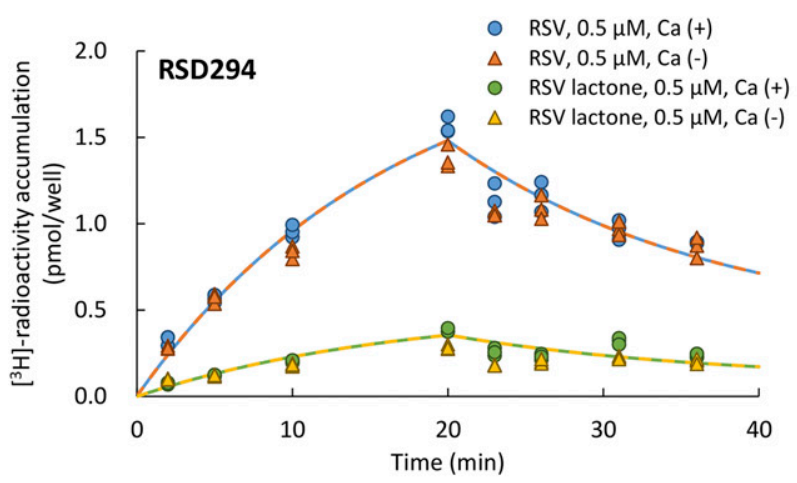

F

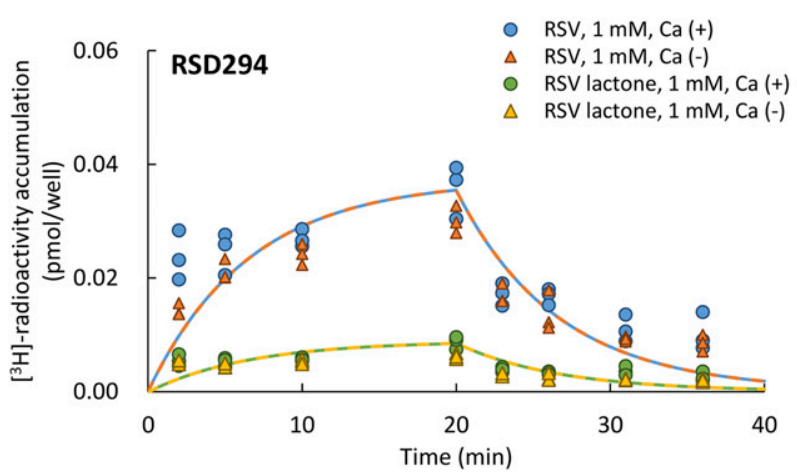

C

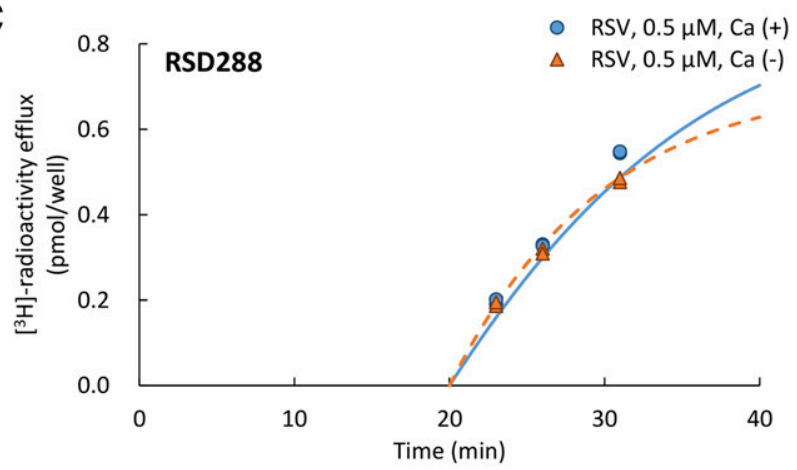

D

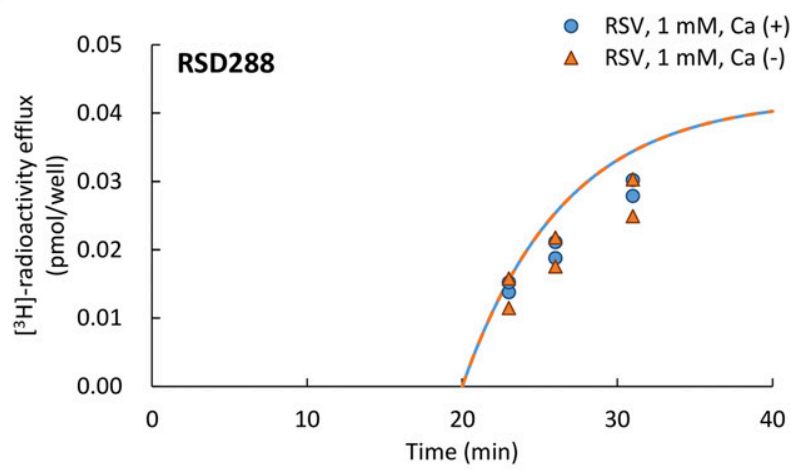

G

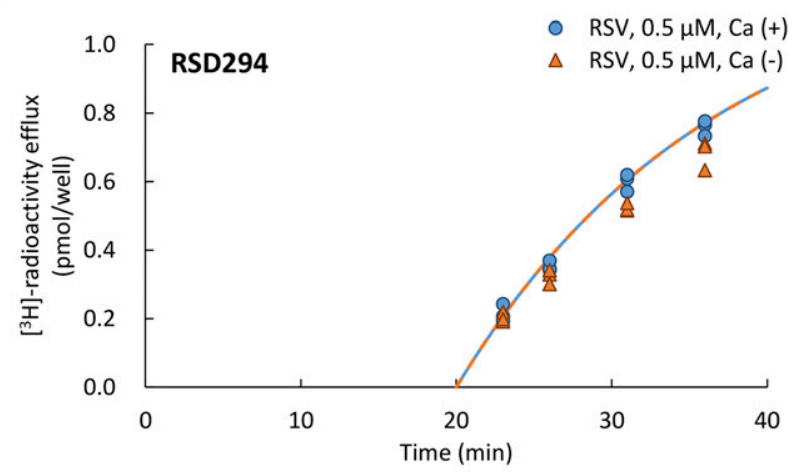

H

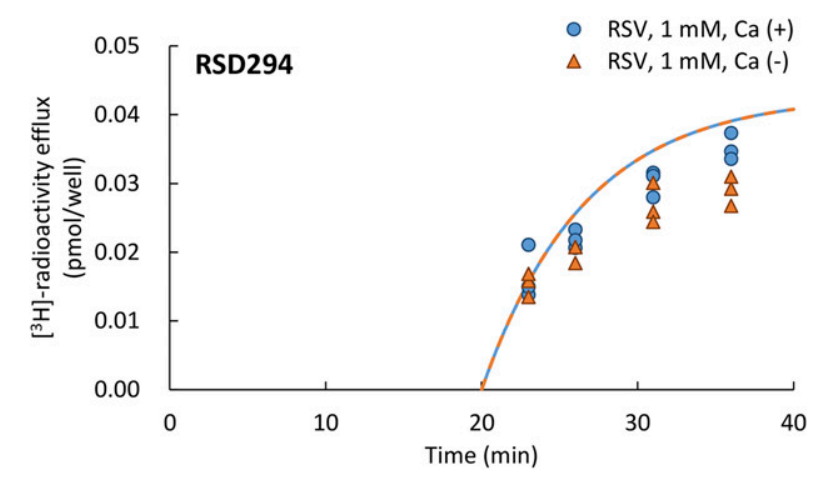

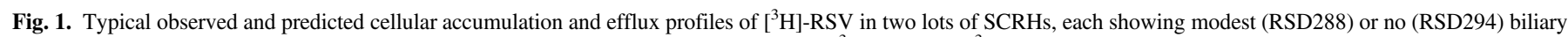

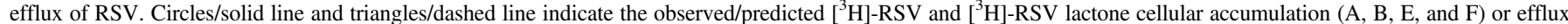

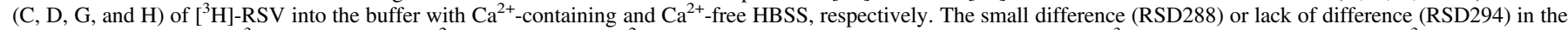

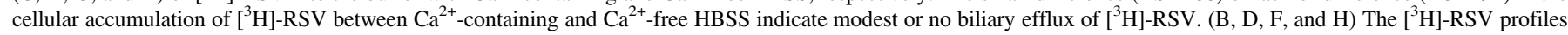
in the presence of unlabeled $1 \mathrm{mM} R S V$. 
of taurocholic acid were reasonable or lower than expected (Supplemental Table 3) (Lee et al., 2010; Li et al., 2010). The mean percentages of $\left[{ }^{3} \mathrm{H}\right]-\mathrm{RSV}$ and $\left[{ }^{3} \mathrm{H}\right]-\mathrm{RSV}$ lactone (in the absence of $1 \mathrm{mM}$ unlabeled RSV) were $67 \%-78 \%$ and $13 \%-21 \%$ in cell lysate samples (Supplemental Table 4). The percentage of RSV in SCRHs was similar to that reported previously (Nezasa et al., 2002). In contrast, all the radioactivity in the buffer samples in the absence of $1 \mathrm{mM}$ unlabeled RSV was in the acid form (Supplemental Table 4). However, due to much lower total cellular radioactivity in the presence of $1 \mathrm{mM}$ unlabeled RSV, we could not quantify the percentage of $\left[{ }^{3} \mathrm{H}\right]$-RSV and $\left[{ }^{3} \mathrm{H}\right]$-RSV lactone in the cell lysates or the buffer samples (data not shown). The mean cellular content values of $\left[{ }^{3} \mathrm{H}\right]-\mathrm{RSV}$ and $\left[{ }^{3} \mathrm{H}\right]-\mathrm{RSV}$ lactone in the SCRHs were used to estimate the hepatobiliary CLs of RSV described below.

Figure 1 and Supplemental Fig. 2 show the cellular accumulation of $\left[{ }^{3} \mathrm{H}\right]-\mathrm{RSV}$ and $\left[{ }^{3} \mathrm{H}\right]-\mathrm{RSV}$ lactone and efflux of $\left[{ }^{3} \mathrm{H}\right]-\mathrm{RSV}$ into the buffer. In three lots of SCRHs (RSD279, RSD288, and Rs14Dec15T), the cellular accumulation of $\left[{ }^{3} \mathrm{H}\right]-\mathrm{RSV}$ in the absence of $1 \mathrm{mM}$ unlabeled $\mathrm{RSV}$ with $\mathrm{Ca}^{2+}$-containing HBSS was modestly higher than that with $\mathrm{Ca}^{2+}$-free HBSS (Fig. 1; Supplemental Fig. 2), whereas in the remaining lots there was no difference. Therefore, $C L_{b i l e}$ could be estimated in only these three lots of SCRHs (Supplemental Table 3; Table 1). The cellular accumulations of $\left[{ }^{3} \mathrm{H}\right]-\mathrm{RSV}$ and $\left[{ }^{3} \mathrm{H}\right]-\mathrm{RSV}$ lactone and $\left[{ }^{3} \mathrm{H}\right]-\mathrm{RSV}$ efflux into the buffer in the presence of $1 \mathrm{mM}$ unlabeled RSV were much lower than that in the absence of $1 \mathrm{mM}$ unlabeled RSV [Fig. 1; Supplemental Fig. 2 (note the difference in scale of the $y$-axis)]. $C L_{s, \text { uptake }}$ of $\left[{ }^{3} \mathrm{H}\right]-\mathrm{RSV}$ was significantly decreased by $1 \mathrm{mM}$ unlabeled RSV, but surprisingly $C L_{s, \text { efflux }}$ of $\left[{ }^{3} \mathrm{H}\right]-\mathrm{RSV}$ was significantly increased by $1 \mathrm{mM}$ unlabeled RSV (Supplemental Table 3; Table 1). In addition, because the cellular accumulation of $\left[{ }^{3} \mathrm{H}\right]-\mathrm{RSV}$ in the presence of $1 \mathrm{mM}$ unlabeled $\mathrm{RSV}$ with $\mathrm{Ca}^{2}$ ${ }^{+}$-containing HBSS was the same as that with $\mathrm{Ca}^{2+}$-free HBSS, $C L_{\text {bile }}$ in the presence of $1 \mathrm{mM}$ unlabeled RSV could not be estimated and was fixed to 0 .

Comparison of Hepatobiliary CL of RSV and Oatp Expression in SCRHs with That Observed In Vivo. Consistent with previous findings (Watanabe et al., 2009; Jones et al., 2012), the in vivo $C L_{s, \text { uptake }}$

\section{TABLE 1}

Estimates of $\left[{ }^{3} \mathrm{H}\right]$-RSV hepatobiliary CLs in SCRHs in the presence of unlabeled $\operatorname{RSV}(0.5 \mu \mathrm{M}$ or $1 \mathrm{mM})$

Data are the mean \pm S.D. of six lots (in the presence of $0.5 \mu \mathrm{M}$ unlabeled RSV) or five lots (in the presence of $1 \mathrm{mM}$ unlabeled RSV) of SCRH.

\begin{tabular}{|c|c|c|}
\hline & \multicolumn{2}{|c|}{$\mathrm{CL}$} \\
\hline & $0.5 \mu \mathrm{M}$ & $1 \mathrm{mM}$ \\
\hline & \multicolumn{2}{|c|}{$\mu \mathrm{l} / \mathrm{min}$ per milligram protein } \\
\hline$C L_{s, \text { uptake }}$ & $27.7 \pm 7.18$ & $2.14 \pm 0.49^{*}$ \\
\hline$C L_{s, e f f l u x}$ & $0.56 \pm 0.40$ & $1.86 \pm 0.95^{*}$ \\
\hline$C L_{\text {bile }}$ & $0.32 \pm 0.24^{a}$ & $0{\text { (fixed })^{b}}^{b}$ \\
\hline$C L_{\text {lac }}$ & \multicolumn{2}{|c|}{$32.1 \pm 14.2$} \\
\hline$C L_{d e-l a c}$ & \multicolumn{2}{|c|}{$142 \pm 70$} \\
\hline$C L_{m e t}$ & \multicolumn{2}{|c|}{$0.097 \pm 0.062^{c}$} \\
\hline $\begin{array}{l}K_{-} \text {flux } \\
\quad\left(\min ^{-1}\right)\end{array}$ & \multicolumn{2}{|c|}{$0.108^{d}$} \\
\hline
\end{tabular}

${ }^{a} C L_{b i l e}$, in the presence of $0.5 \mu \mathrm{M}$ unlabeled RSV was detected in only three lots of SCRHs.

${ }^{b} C L_{\text {bile }}$ in the presence of $1 \mathrm{mM}$ unlabeled RSV was virtually zero and therefore could not be estimated. Consequently, this value was fixed as 0 .

${ }^{c} C L_{m e t}$ could be estimated in only five lots of SCRHs.

${ }^{d} K_{-}$flux could be estimated in only two lots of SCRHs; therefore, only the mean values of $K_{-}$flux are shown.

${ }^{*} P<0.05$ significantly different from the CL in the presence of $0.5 \mu \mathrm{M} \mathrm{CL}$. of RSV was underpredicted by SCRHs (5.50-fold) (Fig. 2). In contrast, in vivo $C L_{s, \text { efflux }}$ and $C L_{\text {bile }}$ were exceedingly well predicted by SCRHs $\left(P>0.05\right.$; Fig. 2). Since only the in vivo $C L_{s, \text { uptake }}$ was underestimated by SCRHs, we determined whether this was due to the difference in expression of Oatps in our SCRHs versus SD liver tissue. Indeed, the expression of all of the Oatps was significantly lower in SCRHs than that in SD liver tissue (Fig. 3).

Scaling RSV $C L_{\text {uptake }}$ in Oatp-Expressing Cells to That in SCRH (In Vitro-to-In Vitro) or That In Vivo Based on Oatp Transporter Expression. After correcting for transporter protein expression, the transporter-mediated intrinsic RSV $C L_{\text {uptake }}$ by Oatp1a1 was higher than that by Oatp1a4 or Oatp1b2 (Table 2). These individual $C L_{\text {uptake }}$ values were scaled to SCRHs using their respective protein expression in SCRHs, and then these scaled-up $C L_{\text {uptake }}$ and $C L_{\text {passive }}$ values estimated from SCRHs and mock cells (Table 3) were summed to recreate in silico the intrinsic $C L_{s, \text { uptake }}$ of RSV in SCRHs (in vitro-in vitro extrapolation) (Fig. 4A). The in silico $C L_{s, \text { uptake }}^{\text {Oatp }+H E K}$ and $C L_{s, \text { uptake }}^{\text {Oatp }+S C R H}$ values were not significantly different from the observed $C L_{s, \text { uptake }}^{S C R H}$ values (not corrected for Oatp protein expression) (Fig. 4A). In contrast, the in silico $C L_{s, \text { uptake }}^{\text {Oatp }+C H O}$ was greater than $C L_{s, \text { uptake }}^{S C R H}$ (Fig. 4A).

The prediction of total (active plus passive) in vivo $C L_{s, \text { uptake }}$ estimated from Oatp-expressing cell lines after correcting for Oatp protein expression was significantly improved compared with $C L_{s, \text { uptake }}$ estimated from SCRH data (without correcting for transporter protein expression) (Fig. 2; Fig. 4B). When compared with $C L_{s, \text { uptake }}^{\text {Oatp }+C H O}, C L_{s, \text { uptake }}^{\text {Oatp }+S C R H}$ or $C L_{s, \text { uptake }}^{\text {Oat }+H E K}$ better approximated our PET imaging data $\left(C L_{s, \text { uptake }}^{\text {PET }}\right)($ Fig. $4 \mathrm{~B})$. However, these three CLs were within 2-fold of the observed value in our PET imaging study $\left(C L_{\text {s.uptake }}^{\text {PET }}\right.$, irrespective of whether $C L_{\text {passive }}$ was estimated from SCRH, CHO-mock cells or HEK293-mock cells (Fig. 4B).

Simulation of Hepatic RSV Concentrations Predicted by Transporter-Based Scaling of RSV Hepatobiliary CL. The mean hepatic concentrations of RSV predicted were based on $C L_{s, \text { efflux }}$ and $C L_{\text {bile }}$ values from SCRHs, and $C L_{s, \text { uptake }}^{\text {Oatp }+S C R H}$ values fell within the $95 \%$ $\mathrm{CI}$ of the concentrations in our previous PET imaging study, suggesting no significant difference between the observed and predicted hepatic concentrations (Fig. 5).

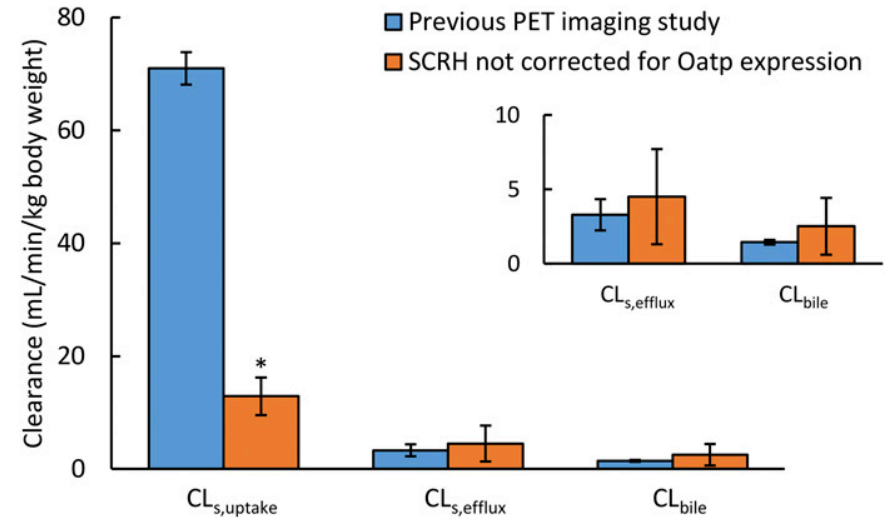

Fig. 2. Comparison of in vivo hepatobiliary clearance of RSV predicted from SCRHs with our previous PET imaging study. RSV $C L_{s, u p t a k e}$ in SCRHs was significantly lower than that observed in our PET imaging study ( $\mathrm{He}$ et al., 2014). In contrast, the in vivo RSV $C L_{s, \text { efflux }}$ and $C L_{b i l e}$ values were well predicted by SCRHs. The inset shows RSV $C L_{s, \text { efflux }}$ and $C L_{\text {bile }}$ values estimated using SCRHs. The data shown are the mean \pm S.D. values from three rats (from our previous PET imaging study), with six lots of SCRHs for $C L_{s, \text { uptake }}$ and $C L_{s, \text { efflux }}$ or three lots of SCRHs for $C L_{\text {bile }}$. ${ }^{*} P<0.05$, significantly different from our previous PET imaging study. 


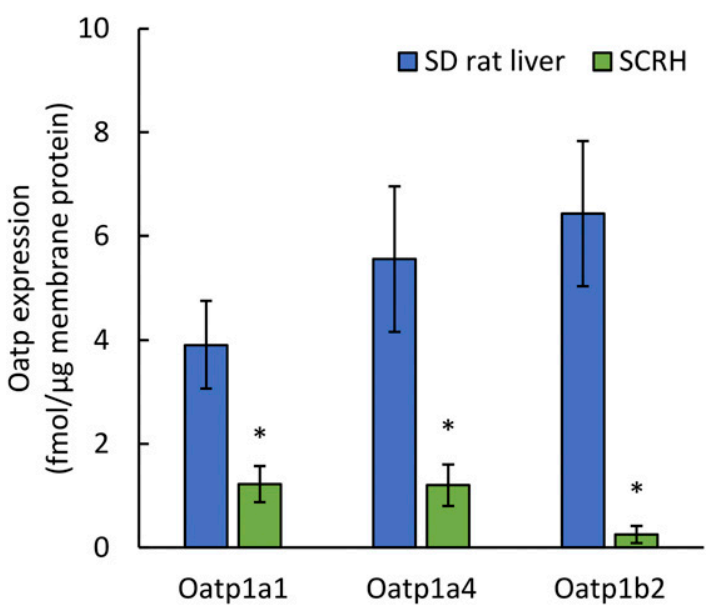

Fig. 3. Oatp protein expression in the SD rat liver and SCRHs. The expression of Oatp transporter proteins in SCRHs was significantly lower than that in the rat liver [data are from the study by Wang et al. (2015)]. The data shown are the mean \pm S.D. of six SD rat livers and three lots of SCRHs. ${ }^{*} P<0.05$, significantly different from SD rat livers.

\section{Discussion}

As we have described before, the hepatic $\mathrm{CL}\left(\mathrm{CL}_{\mathrm{H}}\right)$ of a drug when transporters are involved is determined by the extended CL model (Sirianni and Pang, 1997; Patilea-Vrana and Unadkat, 2016), as follows:

$$
C L_{H}=\frac{Q_{H} \cdot f u C L_{s, \text { uptake }} \cdot\left(C L_{\text {met }}+C L_{\text {bile }}\right)}{Q_{H} \cdot\left(C L_{s, \text { efflux }}+C L_{\text {met }}+C L_{\text {bile }}\right)+f u \cdot C L_{s, \text { uptake }} \cdot\left(C L_{\text {met }}+C L_{\text {bile }}\right)}
$$

where $Q_{H}, f u$, and $C L_{m e t}$ are hepatic blood flow, the unbound fraction in blood and metabolic CL, respectively. Only when $C L_{s, \text { efflux }}<<C L_{\text {met }}+$ $C L_{\text {bile }} \quad$ and $f u \cdot C L_{\text {s,uptake }}<<Q_{H}, \quad C L_{H}=Q_{H} \cdot f u \cdot C L_{s, \text { uptake }} /$ $\left(Q_{H}+f u \cdot C L_{s, \text { uptake }}\right)$ (i.e., when $C L_{s, \text { uptake }}$ is the rate-determining step) (Patilea-Vrana and Unadkat, 2016). When $C L_{s, \text { efflux }}$ is not $<<C L_{m e t}+$ $C L_{\text {bile }}, \mathrm{CL}_{\mathrm{H}}$ will be determined by all CL processes, that is, $C L_{s, \text { uptake }}$, $C L_{s, \text { efflux }}$, and $C L_{\text {bile }}$. Therefore, if $C L_{s, \text { efflux }}$ is assumed to be $<<C L_{\text {met }}+$ $C L_{b i l e}$ when it is not (as in the case of RSV) (Table 1), such an assumption could lead to poor prediction of the $C L_{H}$ of the drug. For this reason, to correctly predict the in vivo hepatic CL of RSV from SCRHs, one must estimate all the relevant CLs (i.e., $C L_{s, \text { uptake }}, C L_{s, \text { efflux }}$, and $C L_{\text {bile }}$ ). Therefore, we estimated all the CLs involved in hepatobiliary CL of RSV in SCRHs. Since we had estimates of all these values from our PET imaging study, we were able to compare the values obtained from SCRHs with those observed in vivo. Our goal was to predict the hepatobiliary CL of RSV within 2-fold to 3-fold of the observed value, since such range of prediction is widely accepted as adequate for IVIVE (Rostami-Hodjegan and Tucker, 2007; Rowland et al., 2011).

\section{TABLE 2}

Protein expression of oatps and transport-mediated intrinsic $C L_{\text {uptake }}$ of RSV in CHO-Oatp1a1, HEK293-Oatp1a4, and HEK293-Oatp1b2 cells

Data are the mean \pm S.D. of triplicate determination. Transporter-mediated uptake CL of RSV was calculated as the ratio of RSV transporter-mediated uptake (uptake in transfected cells minus that in mock cells) over $5 \mathrm{~s}$ (Oatp1a1) or $15 \mathrm{~s}$ (Oatp1a4 and Oatp1b2) and the total buffer RSV concentration $(0.07 \mu \mathrm{M})$.

\begin{tabular}{|c|c|c|c|}
\hline \multirow{2}{*}{$\begin{array}{l}\text { Oatp } \\
\text { Isoform }\end{array}$} & \multirow{2}{*}{$\begin{array}{l}\text { Transporter } \\
\text { Expression }\end{array}$} & \multicolumn{2}{|c|}{ Intrinsic $C L_{\text {uptake }}$} \\
\hline & & $\begin{array}{l}\mu \mathrm{l} / \mathrm{min} \text { per } \mathrm{mg} \\
\text { total protein }\end{array}$ & $\begin{array}{c}\mu \mathrm{l} / \mathrm{min} \text { per } \\
\text { femtomol transporter }\end{array}$ \\
\hline \multicolumn{4}{|c|}{$\mathrm{fmol} / \mu \mathrm{g}$ membrane protein } \\
\hline 1a1 & $6.72 \pm 0.63$ & 459 & 0.113 \\
\hline $1 \mathrm{a} 4$ & $2.61 \pm 0.25$ & 54.0 & 0.043 \\
\hline $1 \mathrm{~b} 2$ & $18.1 \pm 1.79$ & 143 & 0.015 \\
\hline
\end{tabular}

TABLE 3

$C L_{\text {passive }}$ values estimated from SCRHs, CHO-mock cells, and

$$
\text { HEK293-mock cells }
$$

Data shown are the mean \pm S.D. of five lots (SCRHs), three independent experiments (CHOmock cells), or six independent experiments (HEK293-mock cells).

\begin{tabular}{lc}
\hline \multicolumn{1}{c}{ Cells } & $C L_{\text {passive }}$ \\
& \\
\hline & $\mu 1 /$ min per milligram protein \\
SCRH & $2.14 \pm 0.49$ \\
CHO-mock & $47.6 \pm 10.1$ \\
HEK293-mock & $5.68 \pm 0.21$ \\
\hline
\end{tabular}

$C L_{s, \text { uptake }}$ and $C L_{s, \text { efflux }}$ are each a summation of both passive diffusion and/or transporter-mediated CLs, and quantifying the contribution of both pathways is important for IVIVE. In the present study, to estimate passive $C L_{s, \text { uptake }}$, the CL of RSV in SCRHs, unlabeled $1 \mathrm{mM}$ RSV was included in the SCRH studies to inhibit all uptake transporters. Although there are no data on the Michaelis-Menten $\left(\mathrm{K}_{\mathrm{m}}\right)$ constant values of RSV uptake for the rat hepatic transporters, these values for human transporters are less than $70 \mu \mathrm{M}$ (Ho et al., 2006; Kitamura et al., 2008; Bosgra et al., 2014; Kumar et al., 2015). Therefore, we assumed that $1 \mathrm{mM}$ unlabeled RSV completely inhibited all of the rat hepatic transporters. Indeed, this $1 \mathrm{mM}$ unlabeled RSV drastically reduced the $C L_{s, \text { uptake }}$ of $\left[{ }^{3} \mathrm{H}\right]$-RSV in SCRHs. However, surprisingly, $C L_{s, \text { efflux }}$ of $\left[{ }^{3} \mathrm{H}\right]-\mathrm{RSV}$ was significantly increased by $1 \mathrm{mM}$ unlabeled RSV (Supplemental Table 3; Table 1). We do not have a good explanation for this increase. We speculate the following: 1) the higher concentration of the drug in the SCRHs may have saturated intracellular binding of the drug and therefore $C L_{s, \text { efflux }}$ (based on total hepatocyte drug concentration) was increased; 2) we assumed that the metabolism of the drug was not saturated even in the presence of $1 \mathrm{mM}$ unlabeled RSV, but if the RSV metabolites was not a substrate of transporters, inhibition of RSV metabolism might result in an apparent increase in $C L_{s, \text { efflux }}$ of $\left[{ }^{3} \mathrm{H}\right]$ RSV; and 3) metabolites of RSV in SCRH may have stimulated sinusoidal efflux transport (if any) of RSV. RSV is reported to be a substrate of human multidrug resistance-associated protein (MRP) 4, but there are no reports whether rat sinusoidal efflux transporters, such as Mrp3 and Mrp4, can transport RSV. In addition, we have previously reported that Mrp4 in the rat liver tissue and cryopreserved hepatocytes was not detectable by LC-MS/MS (Wang et al., 2015). Further studies are needed to characterize the sinusoidal efflux of RSV and its metabolites in SCRHs.

$C L_{s, \text { efflux }}$ and $C L_{\text {bile }}$ values of RSV determined in SCRHs were not significantly different from those observed in vivo (Fig. 2). $C L_{\text {bile }}$ could be determined in only three lots of SCRHs (Fig. 2) because the remaining lots showed poor biliary CL (Fig. 1; Supplemental Fig. 2; Supplemental Table 3; Table 1). Thus, we used data from the lots where $C L_{\text {bile }}$ was observed based on the assumption that the formation of canalicular junctions may not have been adequate in the lots that showed in RSV $C L_{b i l e}$ values. Although these $C L_{b i l e}$ values were smaller than those reported by Pfeifer et al. (2013b), interestingly they are closer to those observed in vivo values. In contrast, $C L_{s, \text { uptake }}$ of $0.5 \mu \mathrm{M} \mathrm{RSV}$ estimated from SCRHs was significantly lower than that observed in vivo (Fig. 2). Others have also reported (Kotani et al., 2011; Jones et al., 2012) that human SCHs underpredict the observed hepatic CL of drugs. We speculated that this might be due to a decrease in the expression of transporters when the hepatocytes are cultured. Indeed, others have reported (Bi et al., 2013; Badee et al., 2015) that the protein expression of sinusoidal uptake transporters is lower than that in the liver tissue. The protein expression of Oatp1a1, Oatp1a4, and Oatp1b2 in 

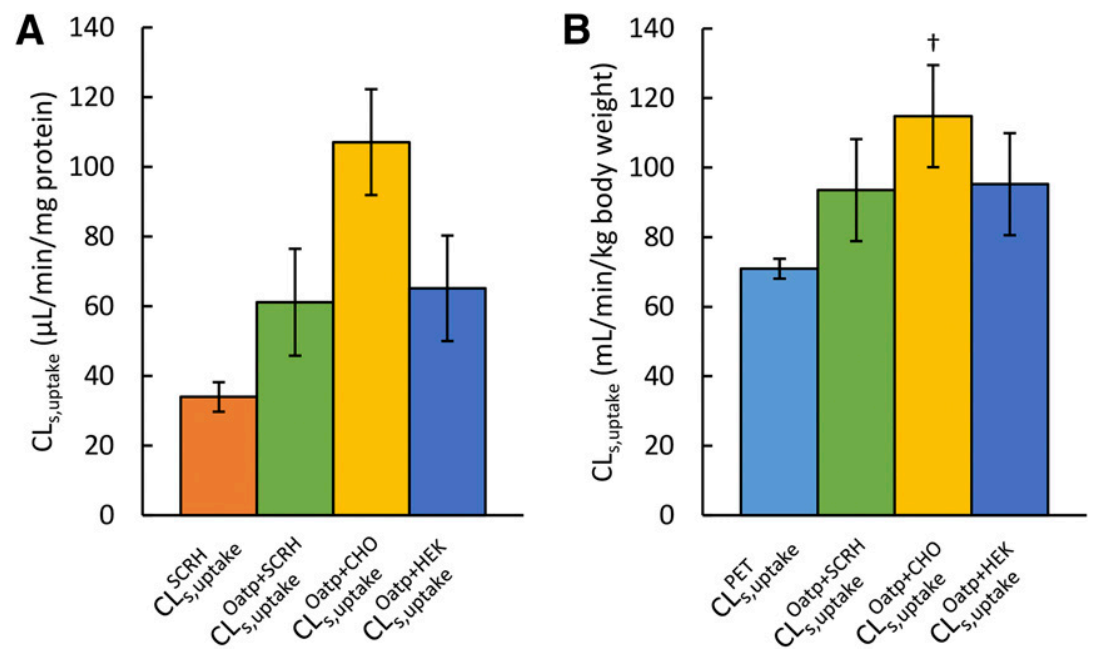

Fig. 4. Comparison of recreated in silico $C L_{\text {s.uptake }}$ of RSV with $C L_{s, \text { uptake }}$ values in SCRHs or from our previous PET imaging study. The recreated in silico RSV $C L_{s, \text { Oatp }+ \text { SCRH }}^{\text {or } C L_{s, p}^{\text {Oat }+H E K}}$ better estimated the observed $C L_{\text {suptake }}$ in SCRHs (A) or in vivo (B). In addition, the recreated in silico $C L_{s, \text { uptake }}^{\text {Oatp }+S C R H}, C L_{s, \text { uptake }}^{\text {Oatp }+C H O}$, $C L_{\text {s.uptake }}^{\text {Oatp }+H E K}$ values of RSV were within 2-fold to 3-fold of $C L_{s, \text { uptake }}$ values estimated from SCRHs (A) or in vivo $C L_{s, \text { uptake }}$ (B). $C L_{s, \text { uptake }}^{S C R H} C L_{s, \text { uptake }}^{\text {Oatp }+S C R H}, C L_{s, \text { uptake }}^{\text {Oatp }+C H O}, C L_{\text {s,uptake }}^{\text {Oatp }+H E K}$, and $C L_{s, \text { uptake }}^{P E T}$ values indicate the total $C L_{s, \text { uptake }}$ values estimated from SCRHs not corrected for the Oatp protein expression, the recreated in silico $C L_{\text {s.uptake }}$ values from Oatp-expressing cells (active) and SCRHs (passive), the recreated in silico $C L_{s, \text { uptake }}$ values from Oatp-expressing cells (active) and CHO-mock cells (passive), the recreated in silico $C L_{s, \text { uptake }}$ values from Oatp-expressing cells (active) and HEK293-mock cells (passive), and total $C L_{s, \text { uptake }}$ values in our previous in vivo PET imaging study, respectively. The data shown are the mean \pm S.D. of three lots of SCRHs, three rats (from our previous PET imaging study, He et al. (2014)), and six rat livers (Wang et al., 2015). $\dagger P<0.05$ significantly different from $C L_{s, \text { uptake }}^{P E T}$

SCRHs was significantly lower than that in the SD rat liver tissue (Fig. 3). This lower expression completely explained the underprediction of the in vivo $C L_{s, \text { uptake }}$ by SCRHs. Of note, the $C L_{s, \text { uptake }}$ values were similar and not significantly different between the SCRH lots where we had measurable RSV $C L_{\text {bile }}$ (RSD279, RSD288, and Rs14Dec15T) and where it was not measurable (RSD270, RSD294, and Rs18Jan16T).

Next, we estimated uptake $C L_{\text {passive }}$ using SCRHs, mock-transfected $\mathrm{CHO}$ cells, or HEK293 cells. $C L_{\text {passive }}$ values estimated from these cell lines were higher than sinusoidal $C L_{\text {passive }}$ values from SCRHs (Table 3 ). We do not know the reasons for this overestimation, but $C L_{\text {passive }}$ in the corresponding mock cells was not dependent on the concentration of the unlabeled RSV used and was not affected by the presence of $100 \mu \mathrm{M}$ rifamycin SV (data not shown). In fact, the $\mathrm{CHO}$ cells drastically overestimated $C L_{\text {passive }}$ uptake in SCRHs. Again, we do not know the reasons for this difference, but it might be due to differences between cells in surface area, membrane composition, and binding of RSV either to the cell surface or to intracellular proteins. Nevertheless, because the Oatp-mediated transport of RSV was the dominant contributor to the sinusoidal uptake of RSV, the in silico $C L_{s, \text { uptake }}\left(\right.$ scaled $_{\text {in }}$ vitro-to - in vitro $)$ value was similar irrespective of whether $C L_{\text {passive }}$ was estimated from SCRHs or HEK293-mock cells and was not significantly different from the observed $C L_{s, u p t a k e}^{S C R H}$ (Fig. 4A) value. In contrast, $C L_{s, \text { uptake }}^{\text {Oatp }+C H O}$ overpredicted the observed $C L_{s, \text { uptake }}^{S C R H}$

The in vivo $C L_{s, \text { uptake }}$ value predicted using Oatp-expressing cells and $C L_{\text {passive }}$ from cell lines or SCRHs was remarkably consistent with that observed in vivo (within 2-fold) irrespective of whether $C L_{\text {passive }}$ was estimated from SCRHs, CHO-mock cells, or HEK293-mock cells (Fig. 4B). As for the in vitro-to-in vitro extrapolation discussed above, the prediction of in vivo $C L_{s, \text { uptake }}$ based on $C L_{s, \text { uptake }}^{\text {Oat }+S C R H}$ or $C L_{s, \text { uptake }}^{\text {Oatp }+H E K}$ better predicted $C L_{s, \text { uptake }}^{P E T}$. Predictions based on $C L_{s, \text { uptake }}^{\text {Oat }+C H O}$ values were within 2-fold because Oatp transport of RSV was the dominant process, with passive diffusion playing a minor role. However, for another drug this might not be the case. Thus, we propose that until additional data are obtained indicating the contrary, for drugs where the $C L_{\text {passive }}$ value is significant, this value be estimated from $\mathrm{SCHs}$ (using selective inhibitors of the uptake transporter) or HEK293-mock cells.

Besides, $C L_{s, \text { uptake }}^{P E T}$, the observed hepatic concentrations of RSV were well predicted by $C L_{s, \text { uptake }}^{\text {Oatp }+S C R H}$. The predicted values fell within the $95 \% \mathrm{CI}$ of the observed values, indicating no significant difference between these values (Fig. 5). Although the predicted hepatic $C_{\max }$ value of RSV was greater than the observed value, this discrepancy was expected because the mean value of the $C L_{s, \text { uptake }}^{\text {Oat }+S C R H}$ was greater than that observed in vivo $\left(C L_{s, \text { uptake }}^{P E T}\right)$. In addition, the half-life of the drug estimated from SCRHs was shorter than that in our previous

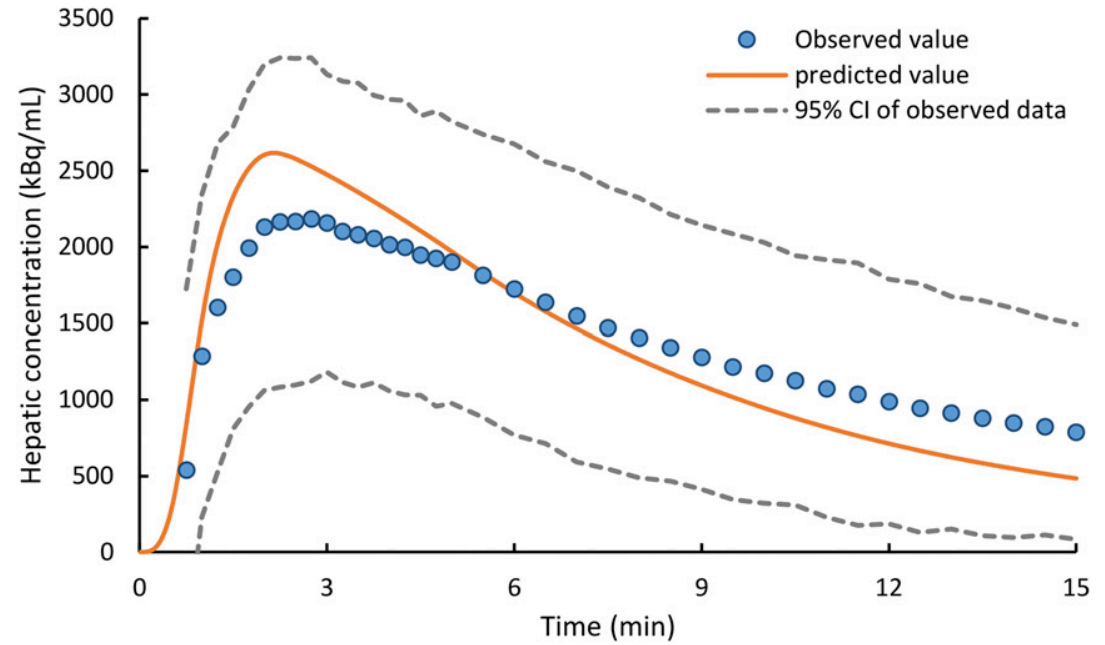

Fig. 5. Simulated RSV hepatic concentrations based on hepatobiliary clearances of the drug estimated from Oatpexpressing cells and SCRHs. The mean predicted hepatic concentration of RSV (orange solid line), generated from the estimated $C L_{s, u p t a k e}^{\text {Oatp }+S C R H}, C L_{s, \text { efflux }}$, and $C L_{\text {bile }}$ values from SCRHs (see Materials and Methods), fell within the $95 \%$ CI of the observed concentrations in our previous in vivo PET imaging study (blue circles and gray dashed lines) (He et al., 2014), suggesting an excellent agreement between the observed and predicted hepatic RSV concentrations. 
in vivo PET imaging study, because the mean values of $C L_{s . e f f l u x}$ and $C L_{\text {bile }}$ in SCRHs were greater than those observed in vivo (Fig. 2). Since the values of $C L_{s, \text { uptake }}^{\text {Oatp }+S C R H}$ and $C L_{\text {s,uptake }}^{\text {Oatp }+H E K}$ are almost identical, the latter would also predict the observed hepatic concentrations of RSV equally well in our PET imaging study.

Our proposed approach has some limitations. First, it requires that the quantitative targeted proteomics method be available. Second, it assumes that the transporter abundance measured reflects functional transporters present on the cell surface. The latter is partially overcome by quantifying cell surface expression of the transporter using a refined biotinylation method that we have recently published (Kumar et al., 2017).

In conclusion, this is the first report of the successful prediction of in vivo hepatic concentrations as well as hepatobiliary CLs of a drug from studies in transporter-expressing cell lines (scaled by Oatp protein abundance) and SCRHs. Our data clearly demonstrate that the underprediction of $C L_{s, \text { uptake }}$ of RSV was due to the lower expression of Oatps in SCRHs versus liver tissue. We speculate that such lower expression of transporters may also explain the underprediction of hepatic CL of other drugs based on $\mathrm{SCH}$ studies. Thus, we recommend that transporter expression is measured in in vitro systems used to predict in vivo hepatobiliary CL of drugs. In addition, our studies demonstrate the promise of using transporterexpressing cells to directly predict $C L_{s, \text { uptake }}$ of drugs. As noted earlier, scaling Oatp $C L_{\text {uptake }}$ values in cell lines to SCRHs and then in vivo using transporter expression data is equivalent to directly scaling $C L_{\text {uptake }}$ values from cell lines to in vivo (eq. 9) (see Materials and Methods). There is no reason why this approach could not be used to also predict sinusoidal and canalicular efflux CL of drugs, thus avoiding the use of SCHs and the disadvantage of the RAF approach inherent to Oatp substrates. Therefore, we propose that studies be conducted to determine whether our approach can be generalized to successfully predict hepatobiliary CL and hepatic concentrations of drugs other than RSV, especially in humans. This, of course, will require that data from imaging studies in humans are available. Fortunately, such data are becoming increasingly available (Shimizu et al., 2012; Takashima et al., 2012).

\section{Acknowledgments}

We thank Dr. Bhagwat Prasad and Dr. Sarah Billington for technical help in LC-MS/MS protein quantification.

\section{Authorship Contributions}

Participated in research design: Ishida, Ullah, and Unadkat.

Conducted experiments: Ishida.

Contributed new reagents or analytic tools: Tóth and Juhasz.

Performed data analysis: Ishida.

Wrote or contributed to the writing of the manuscript: Ishida, Ullah, Tóth, Juhasz, and Unadkat.

\section{References}

Abe K, Bridges AS, Yue W, and Brouwer KL (2008) In vitro biliary clearance of angiotensin II receptor blockers and 3-hydroxy-3-methylglutaryl-coenzyme A reductase inhibitors in sandwichcultured rat hepatocytes: comparison with in vivo biliary clearance. J Pharmacol Exp Ther 326: 983-990.

Badée J, Achour B, Rostami-Hodjegan A, and Galetin A (2015) Meta-analysis of expression of hepatic organic anion-transporting polypeptide (OATP) transporters in cellular systems relative to human liver tissue. Drug Metab Dispos 43:424-432.

Bi YA, Qiu X, Rotter CJ, Kimoto E, Piotrowski M, Varma MV, Ei-Kattan AF, and Lai Y (2013) Quantitative assessment of the contribution of sodium-dependent taurocholate co-transporting polypeptide (NTCP) to the hepatic uptake of rosuvastatin, pitavastatin and fluvastatin. Biopharm Drug Dispos 34:452-461.

Bosgra S, van de Steeg E, Vlaming ML, Verhoeckx KC, Huisman MT, Verwei M, and Wortelboe HM (2014) Predicting carrier-mediated hepatic disposition of rosuvastatin in man by scaling from individual transfected cell-lines in vitro using absolute transporter protein quantification and PBPK modeling. Eur J Pharm Sci 65:156-166.

Chapy H, Klieber S, Brun P, Gerbal-Chaloin S, Boulenc X, and Nicolas O (2015) PBPK modeling of irbesartan: incorporation of hepatic uptake. Biopharm Drug Dispos 36:491-506.
Fukuda H, Ohashi R, Tsuda-Tsukimoto M, and Tamai I (2008) Effect of plasma protein binding on in vitro-in vivo correlation of biliary excretion of drugs evaluated by sandwich-cultured rat hepatocytes. Drug Metab Dispos 36:1275-1282.

He J, Yu Y, Prasad B, Link J, Miyaoka RS, Chen X, and Unadkat JD (2014) PET imaging of Oatpmediated hepatobiliary transport of [(11)C] rosuvastatin in the rat. Mol Pharm 11:2745-2754.

Hirano M, Maeda K, Shitara Y, and Sugiyama Y (2004) Contribution of OATP2 (OATP1B1) and OATP8 (OATP1B3) to the hepatic uptake of pitavastatin in humans. J Pharmacol Exp Ther 311:139-146.

Hirano M, Maeda K, Shitara Y, and Sugiyama Y (2006) Drug-drug interaction between pitavastatin and various drugs via OATP1B1. Drug Metab Dispos 34:1229-1236.

Ho RH, Tirona RG, Leake BF, Glaeser H, Lee W, Lemke CJ, Wang Y, and Kim RB (2006) Drus and bile acid transporters in rosuvastatin hepatic uptake: function, expression, and pharmacogenetics. Gastroenterology 130:1793-1806.

Jones HM, Barton HA, Lai Y, Bi YA, Kimoto E, Kempshall S, Tate SC, El-Kattan A, Houston JB, Galetin A, et al. (2012) Mechanistic pharmacokinetic modeling for the prediction of transportermediated disposition in humans from sandwich culture human hepatocyte data. Drug Metab Dispos 40:1007-1017.

Ke AB, Nallani SC, Zhao P, Rostami-Hodjegan A, and Unadkat JD (2014) Expansion of a PBPK model to predict disposition in pregnant women of drugs cleared via multiple CYP enzymes, including CYP2B6, CYP2C9 and CYP2C19. Br J Clin Pharmacol 77:554-570.

Kimoto E, Bi YA, Kosa RE, Tremaine LM, and Varma MVS (2017) Hepatobiliary clearance prediction: species scaling from monkey, dog, and rat, and in vitro-in vivo extrapolation of sandwich-cultured human hepatocytes using 17 drugs. J Pharm Sci 106:2795-2804

Kitamura S, Maeda K, Wang Y, and Sugiyama Y (2008) Involvement of multiple transporters in the hepatobiliary transport of rosuvastatin. Drug Metab Dispos 36:2014-2023.

Kotani N, Maeda K, Watanabe T, Hiramatsu M, Gong LK, Bi YA, Takezawa T, Kusuhara H, and Sugiyama Y (2011) Culture period-dependent changes in the uptake of transporter substrates in sandwich-cultured rat and human hepatocytes. Drug Metab Dispos 39:1503-1510.

Kumar V, Prasad B, Patilea G, Gupta A, Salphati L, Evers R, Hop CE, and Unadkat JD (2015) Quantitative transporter proteomics by liquid chromatography with tandem mass spectrometry: addressing methodologic issues of plasma membrane isolation and expression-activity relationship. Drug Metab Dispos 43:284-288.

Kumar V, Nguyen TB, Tóth B, Juhasz V, and Unadkat JD (2017) Optimization and application of a biotinylation method for quantification of plasma membrane expression of transporters in cells. AAPS $J$ [published ahead of print].

Kunze A, Huwyler J, Camenisch G, and Poller B (2014) Prediction of organic anion-transporting polypeptide 1B1- and 1B3-mediated hepatic uptake of statins based on transporter protein expression and activity data. Drug Metab Dispos 42:1514-1521.

Lee JK, Paine MF, and Brouwer KL (2010) Sulindac and its metabolites inhibit multiple transport proteins in rat and human hepatocytes. J Pharmacol Exp Ther 334:410-418.

Li N, Singh P, Mandrell KM, and Lai Y (2010) Improved extrapolation of hepatobiliary clearance from in vitro sandwich cultured rat hepatocytes through absolute quantification of hepatobiliary transporters. Mol Pharm 7:630-641.

Ménochet K, Kenworthy KE, Houston JB, and Galetin A (2012) Use of mechanistic modeling to assess interindividual variability and interspecies differences in active uptake in human and rat hepatocytes. Drug Metab Dispos 40:1744-1756.

Nakakariya M, Shimada T, Irokawa M, Koibuchi H, Iwanaga T, Yabuuchi H, Maeda T, and Tamai I (2008a) Predominant contribution of rat organic anion transporting polypeptide-2 (Oatp2) to hepatic uptake of beta-lactam antibiotics. Pharm Res 25:578-585.

Nakakariya M, Shimada T, Irokawa M, Maeda T, and Tamai I (2008b) Identification and species similarity of OATP transporters responsible for hepatic uptake of $\beta$-lactam antibiotics. Drug Metab Pharmacokinet 23:347-355.

Nezasa K, Takao A, Kimura K, Takaichi M, Inazawa K, and Koike M (2002) Pharmacokinetics and disposition of rosuvastatin, a new 3-hydroxy-3-methylglutaryl coenzyme A reductase inhibitor, in rat. Xenobiotica 32:715-727.

Ohtsuki S, Uchida Y, Kubo Y, and Terasaki T (2011) Quantitative targeted absolute proteomicsbased ADME research as a new path to drug discovery and development: methodology, advantages, strategy, and prospects. J Pharm Sci 100:3547-3559.

Patilea-Vrana G and Unadkat JD (2016) Transport vs. metabolism: what determines the pharmacokinetics and pharmacodynamics of drugs? insights from the extended clearance model. Clin Pharmacol Ther 100:413-418.

Pfeifer ND, Bridges AS, Ferslew BC, Hardwick RN, and Brouwer KL (2013a) Hepatic basolateral efflux contributes significantly to rosuvastatin disposition II: characterization of hepatic elimination by basolateral, biliary, and metabolic clearance pathways in rat isolated perfused liver. $J$ Pharmacol Exp Ther 347:737-745.

Pfeifer ND, Yang K, and Brouwer KL (2013b) Hepatic basolateral efflux contributes significantly to rosuvastatin disposition I: characterization of basolateral versus biliary clearance using a novel protocol in sandwich-cultured hepatocytes. J Pharmacol Exp Ther 347:727-736.

Pfeifer ND, Hardwick RN, and Brouwer KL (2014) Role of hepatic efflux transporters in regulating systemic and hepatocyte exposure to xenobiotics. Annu Rev Pharmacol Toxicol 54:509-535.

Prasad B and Unadkat JD (2014) Comparison of heavy labeled (SIL) peptide versus SILAC protein internal standards for LC-MS/MS quantification of hepatic drug transporters. Int J Proteomics 2014:451510.

Prasad B and Unadkat JD (2015) The concept of fraction of drug transported (ft ) with special emphasis on BBB efflux of CNS and antiretroviral drugs. Clin Pharmacol Ther 97:320-323.

Rostami-Hodjegan A and Tucker GT (2007) Simulation and prediction of in vivo drug metabolism in human populations from in vitro data. Nat Rev Drug Discov 6:140-148.

Rowland M, Peck C, and Tucker G (2011) Physiologically-based pharmacokinetics in drug development and regulatory science. Annu Rev Pharmacol Toxicol 51:45-73.

Shimizu K, Takashima T, Yamane T, Sasaki M, Kageyama H, Hashizume Y, Maeda K, Sugiyama Y, Watanabe Y, and Senda M (2012) Whole-body distribution and radiation dosimetry of [11C]telmisartan as a biomarker for hepatic organic anion transporting polypeptide (OATP) 1B3. Nucl Med Biol 39:847-853.

Sirianni GL and Pang KS (1997) Organ clearance concepts: new perspectives on old principles. $J$ Pharmacokinet Biopharm 25:449-470.

Soars MG, McGinnity DF, Grime K, and Riley RJ (2007) The pivotal role of hepatocytes in drug discovery. Chem Biol Interact 168:2-15.

Swift B, Pfeifer ND, and Brouwer KL (2010) Sandwich-cultured hepatocytes: an in vitro model to evaluate hepatobiliary transporter-based drug interactions and hepatotoxicity. Drug Metab Rev 42:446-471.

Takashima T, Kitamura S, Wada Y, Tanaka M, Shigihara Y, Ishii H, Ijuin R, Shiomi S, Nakae T, Watanabe Y, et al. (2012) PET imaging-based evaluation of hepatobiliary transport in humans with (15R)-11C-TIC-Me. J Nucl Med 53:741-748. 
Vildhede A, Mateus A, Khan EK, Lai Y, Karlgren M, Artursson P, and Kjellsson MC (2016) Mechanistic modeling of pitavastatin disposition in sandwich-cultured human hepatocytes: a proteomics-informed bottom-up approach. Drug Metab Dispos 44:505-516.

Wang L, Prasad B, Salphati L, Chu X, Gupta A, Hop CE, Evers R, and Unadkat JD (2015) Interspecies variability in expression of hepatobiliary transporters across human, dog, monkey, and rat as determined by quantitative proteomics. Drug Metab Dispos 43:367-374.

Watanabe T, Kusuhara H, Maeda K, Shitara Y, and Sugiyama Y (2009) Physiologically based pharmacokinetic modeling to predict transporter-mediated clearance and distribution of pravastatin in humans. J Pharmacol Exp Ther 328:652-662.

Wolf KK, Vora S, Webster LO, Generaux GT, Polli JW, and Brouwer KL (2010) Use of cassette dosing in sandwich-cultured rat and human hepatocytes to identify drugs that inhibit bile acid transport. Toxicol In Vitro 24:297-309.
Yamashiro W, Maeda K, Hirouchi M, Adachi Y, Hu Z, and Sugiyama Y (2006) Involvement of transporters in the hepatic uptake and biliary excretion of valsartan, a selective antagonist of the angiotensin II AT1-receptor, in humans. Drug Metab Dispos 34:1247-1254.

Zou P, Liu X, Wong S, Feng MR, and Liederer BM (2013) Comparison of in vitro-in vivo extrapolation of biliary clearance using an empirical scaling factor versus transport-based scaling factors in sandwich-cultured rat hepatocytes. J Pharm Sci 102:2837-2850.

Address correspondence to: Jashvant D. Unadkat, Department of Pharmaceutics, Box 357610, University of Washington, Seattle, WA 98195. E-mail: jash@uw.edu 